Journal

of Geography,

Politics and Society

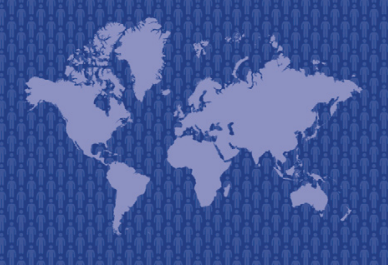

$9(3) / 2019$

\section{Journal of Geography, Politics and Society}

$2019,9(3), 42-49$

https://doi.org/10.26881/jpgs.2019.3.06

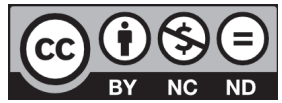

\title{
CHANGES ON THE TOURISM SERVICES MARKET IN MONTENEGRO
}

\section{IN 2007-2017}

\author{
Wioletta Szymańska (1), Anna Wiśniewska (2) \\ (1) Institute of Geography and Regional Studies, Pomeranian University, Partyzantów 27, 76-200 Słupsk, Poland, ORCID 0000-0001-8673-2074 \\ e-mail: wioletta.szymanska@apsl.edu.pl (corresponding author) \\ (2) Institute of Geography and Regional Studies, Pomeranian University, Partyzantów 27, 76-200 Słupsk, Poland, ORCID 0000-0001-5925-330X \\ e-mail: anna.wisniewska@apsl.edu.pl
}

\section{Citation}

Szymańska W., Wiśniewska A., 2019, Changes on the tourism services market in Montenegro in 2007-2017, Journal of Geography, Politics and Society, 9(3), 42-49.

\begin{abstract}
The aim of the article is to discuss the changes on the tourism services market in Montenegro. The article presents statistical data on tourist traffic and the use of accommodation facilities both nationally and regionally. It focuses on domestic and inbound tourism with special emphasis placed on the citizens of Serbia, Russia, Bosnia and Herzegovina. It is assumed that the seaside location is of utmost importance for Montenegrin tourism as increased tourist traffic can be observed in the coastal zone. It is also stated that the biggest threat to the development of Montenegrin tourism is not enough diversity in international tourist arrivals.
\end{abstract}

\section{Key words}

accommodation, former Yugoslavia, Montenegro, tourism.

\section{Introduction}

Tourism is one of the fastest-growing sectors of economy in the world. It is a consequence of economic factors (i.e. increase in the income of the population, favourable market conditions, financial stability of areas of tourist reception), social factors (life expectancy, holidays, non-working days), political factors (economic policy, foreign policy, fiscal policy, social policy, international integration), technical factors (transport infrastructure, accommodation and gastronomy facilities) and ecological factors (Čerović et al., 2016). All of the above mentioned factors influence the development of tourism. On the other hand, tourism influences the factors that facilitate its growth (Tkalec, Vizek, 2016).

Being one of the youngest countries in the world, Montenegro is also the youngest country recognised by other countries after the breakup of Yugoslavia. Thanks to its peaceful separation from Serbia based on a referendum held on 21 May 2006, the country was spared disruptive fighting. The peaceful separation of Montenegro from Yugoslavia resulted in the increase of the tourists numbers by $76 \%$ from 1.133 million in 2007 to 2 million in 2017. At the same time, the number of domestic tourists decreased by 
over 26 thousand compared to the extreme years of the period under research, whereas the number of foreign tourists increased by 893 thousand. Such growth of tourist traffic in Montenegro should seem satisfactory. However, it should be noted that a majority of international arrivals come from three countries: Serbia, Russia and Herzegovina (Cimbaljević et al., 2019; Violante, 2017). While analyzing the statistical data, lack of effective actions aiming to diversify the tourist traffic source markets can be noted.

\section{Research data and methods}

Statistical data on tourist traffic and the use of accommodation facilities in Montenegro for the period 2007-2017 were applied in the study. Also, data on the number of arrivals and the number of overnight stays of the national groups participating in the tourism traffic in Montenegro were used. The timeframes result from the applied research methodology. Despite the fact that Montenegro declared independence in June 2006 i.e., before the beginning of the tourist season, the published statistical data for 2006 include Serbs as domestic tourists. Therefore, the data for 2006 cannot be compared with statistical data for subsequent years. Data for 2018 are not taken into consideration in this article as they were not available at the time.

Classic statistical measures used in the study include arithmetic mean and the population standard deviation. Those measures allowed to estimate the coefficient of variation as the measure of dispersion. The power of dispersion was interpreted on the basis of the obtained results in the following way (Wiskulski, 2019):

- 0\%-20\% low variation;

- 20\%-40\% moderate variation;

- 40\%-60\% high variation;

- $60 \%$ and more - very high variation.

The statistical data were obtained from statistical yearbooks of Montenegro (Statistical..., 2009, 2013, 2018).

While analyzing the situation on the Montenegrin market of accommodation services and the fluctuations of the tourist traffic, the country was divided into zones based on the geographical conditions. The following zones were distinguished: the coastal zone including districts with direct access to the Adriatic, the mountain zones, Podgorica, other tourist areas and other places. The distinction of the first three zones seems significant as each of those types of zones has individual features differentiating it from the others. Longer overnight stays and mostly stationary character is typical for the coastal tourism. Tourism in the mountain area is mostly activity-based tourism involving change of accommodation - a phenomenon observed through an analysis of average length of stay. On the other hand, tourism in Podgorica involves mostly sightseeing. Moreover, due to the fact that it is a capital city, users of its accommodation facilities may not arrive there for tourist purposes but on business. Research on tourist traffic in Montenegro has been conducted for many years. Geographic information system (GIS) has been applied to carry out those analyses (Cimbaljević et al., 2019; Statuto, 2017). The research mostly concentrated on an evaluation of tourist attraction of the country (Djurović, Djurović, 2016; Marti, Puertas, 2017). Also, sustainable development of tourism is a significant part of the research (Smolović et al., 2018; Vučetić, 2017). The authors draw attention to the excessive exploitation of the tourist areas in Montenegro and point to the threats it entails (Šilc et al., 2016). There were also surveys on the innovative and competitive character of Montenegrin accommodation facilities (Marušić et al., 2019; Srdanović, Dragoslav, 2015; Vučetić, 2018).

\section{Variation in the tourist traffic volumes}

Similarly to Croatia, the biggest increase in the number of tourists occurred in the seaside destinations - nearly 706 thousand tourists, i.e. $69.8 \%$. They constituted from $88.4 \%$ to $90.7 \%$ of the population over the period 2007-2017 (fig.1). Podgorica was the second most popular seaside destination. Tourists visiting the capital constituted $3.7 \%$ to $7.3 \%$. Equally important tourist destinations are mountain resorts which attracted $3 \%$ to $4.2 \%$ of tourists. Podgorica was characterised by the highest variation coefficient for the number of tourists estimated at $40.93 \%$ which indicates a high variation in the number of tourists. On the other hand, the variation coefficient for the mountain resorts was estimated at $26.24 \%$ this value means moderate variation in the number of tourists. The lowest value of the coefficient was estimated for the seaside area at $17.1 \%$. Due to the prevailing participation of tourists visiting seaside destinations, the variation coefficient calculated for the whole territory of Montenegro was $18.09 \%$, which is evidence of low variation in the number of tourists.

Tourists to Montenegro made up 7.29 million overnight stays in 2007. The number was growing continuously to reach 11.95 million in 2017 which means a rise by $63.87 \%$. A majority of overnight stays was made in the seaside destinations and accounted for $94.9 \%-97.0 \%$ of the total number of overnight stays. Similarly to the number of tourists, the second 


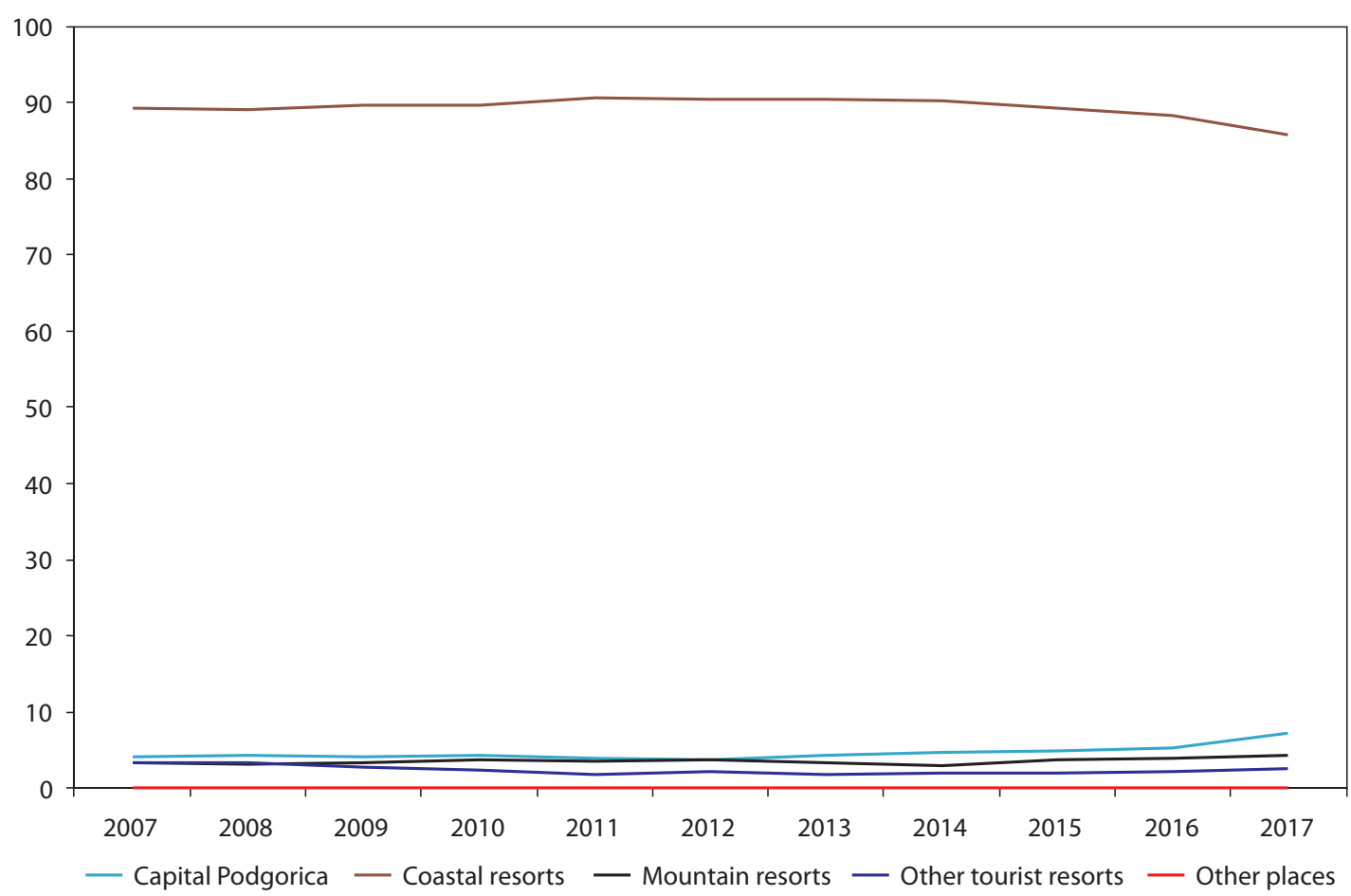

Fig. 1. The structure (in \%) of the number of tourists in designated areas in Montenegro.

Source: own study based on: Statistical..., 2009, 2013, 2018.

most popular area for overnight stays was Podgorica. From $1.1 \%$ to $2.2 \%$ of overnight stays were made in its area. The third area with the highest number of overnight stays were mountain resorts where $0.9 \%$ to $1.6 \%$ of overnight stays were made. The variation coefficient calculated for Podgorica was the highest of the three designated areas and was $34.41 \%$, thus it can be concluded that the variation in overnight stays in the period under research was moderate. On the other hand, the variation coefficient calculated for the number of overnight stays in mountain resorts was $23.29 \%$ which means this is an area of moderate variation of the analyzed feature. The lowest variation coefficient was estimated for the seaside destinations at $16.39 \%$ i.e., a little lower than for the entire area of Montenegro (16.43\%).

The average number of overnight stays for tourists in the period under study was between 5.986.56. Values exceeding the national average were characteristic of only the seaside destinations where the average length of stay was between $6.61-7.05$ nights. In Podgorica, the average length of stay was between 1.79-2.21 nights while in the third most frequently visited area i.e., the mountain area, the average length of stay was 1.99-2.68 nights. Such low results outside the coastal area are a logical consequence of the specific forms of tourism done there. In the case of Podgorica, the stays are short which may result from the capital character of the area, so people classified as tourists may not necessarily possess tourist characteristics but they may visit it for business purposes. In the mountain areas, the stays may be short because of hiking which entails frequent changes of places of stay. However, it must be emphasized that moving around constantly leads to artificial overstating of the official numbers. Only coastal tourism is stationary thus should not lead to falsifying data.

\section{Domestic tourism}

In 2007, tourists identifying themselves as Montenegrins accounted for $13 \%$ of the total number of tourist traffic participants (149 thousand). In subsequent years, the participation of domestic tourists decreased systematically to $6.14 \%$ (123 thousand). Similarly to the entire tourist population, seaside destinations were also the most popular with Montenegrins. In 2007 , they accounted for $73.4 \%$ of domestic tourists (fig. 2.). Their participation fluctuated in subsequent years to fall as low as $55.1 \%$ in 2017. The second most popular tourist destination in Montenegro are the mountains. Tourists staying in this area in 2007 accounted for $11.9 \%$ of the total number of domestic tourists and their number decreased to $6.4 \%$ by 2014 . Then, it increased to $16.5 \%$ by 2017 . The third most popular tourist destination was Podgorica. In 2007, the participation of tourists visiting this place was $3.6 \%$ only to grow up to $11.8 \%$ in subsequent years. The highest value of the variation coefficient for Podgorica was estimated at $38.07 \%$. That 


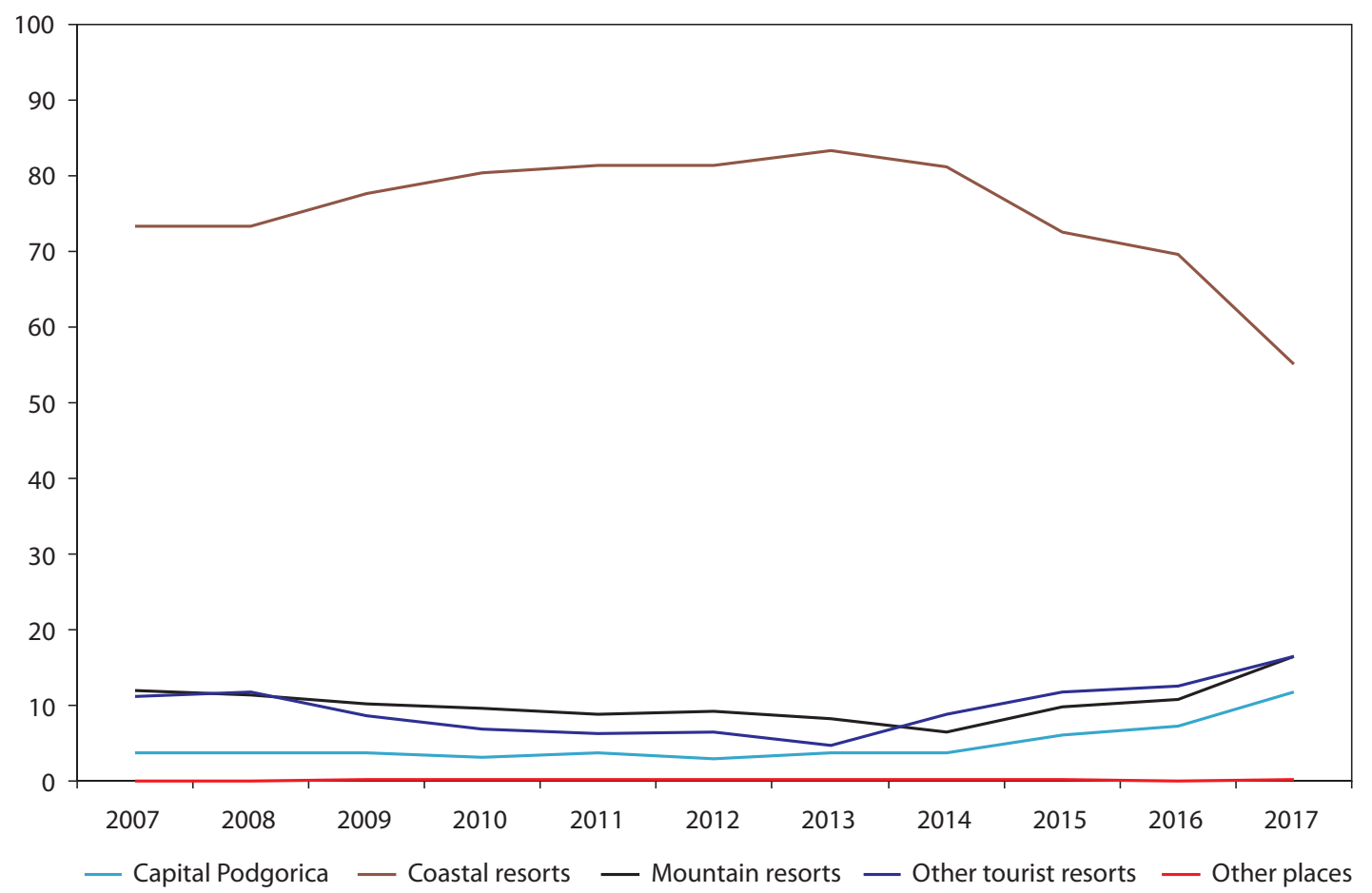

Fig. 2. The structure (in \%) of the number of tourists in designated areas in Montenegro.

Source: own study based on: Statistical..., 2009, 2013, 2018.

is evidence of moderate variation in the number of tourist traffic participants. However, the variation coefficient for the seaside destinations was estimated at $17.86 \%$ - low variation. However, the coefficient for mountain destinations was estimated at $14.71 \%$ which indicates low variation of the analyzed values. The coefficient for the entire Montenegro's territory was estimated at $9.18 \%$ which makes it an area of low variation in domestic tourists numbers.

In 2007, Montenegrins accounted for $11.66 \%$ (852 thousand) of overnight stays in the accommodation facilities of Montenegro. These values remained at a similar level until 2014. Despite an increase of the absolute value in the number of overnight stays since 2015 , it decreased to $4.04 \%$ (483 thousand) in 2017. A majority of overnight stays was made in the seaside destinations. 698 thousand of overnight stays were made in 2007 , which accounted for $82 \%$. Their percentage and absolute value increased by 2013 when it reached the level of 918 thousand of overnight stays (they accounted for $92 \%$ of all overnight stays made by Montenegrins). Over the years 2014-2017, the number of overnight stays decreased to 352 thousand in 2017, which made up $72.9 \%$ of all overnight stays. The second area in terms of the highest number of overnight stays are mountain destinations. 7.1\% (60.7 thousand) of all overnight stays were made by Montenegrins in this area in 2007. Then, their participation fell to $2.6 \%$ in 20014 . Then, an increase up to $8.5 \%$ was observed in the years 2015-2017. In Podgorica, overnight stays made by Montenegrins accounted for $2.9 \%$ (24.8 thousand) in 2007. Despite the small percentage, their absolute value was the highest until 2016 when it reached 3.7\% (26.5 thousand). The highest value of the coefficient was calculated for Podgorica at $27.5 \%$ thus indicating a moderate variation in the analyzed feature. On the other hand, the coefficient value estimated for mountain areas at $25.53 \%$ indicates moderate variation in the analyzed feature. The estimated value for seaside destinations was $22.09 \%$, which indicates a moderate variation in the feature in the period under study.

The average number of overnight stays in domestic tourism ranged from 3.93-5.95 in the years of 2007-2017. Obviously, the highest values were estimated for the coastal areas at the level of 5.21-6.58. In the mountain region, the number of overnight stays in the years under study was $2.04-3.63$ while in Podgorica, the values ranged from 2.28 to 4.60.

\section{Inbound tourism}

Since the declaration of independence, international tourists in Montenegro constituted a majority. In 2007 they accounted for nearly $87 \%$ of tourists. Their participation in the structure of the tourist traffic increased and was as high as $93.86 \%$ in 2017 . The seaside destinations were most frequently chosen by international tourists and were visited by $92.6 \%$ (901 thousand) of all foreign tourists in 2007 (fig. 3). 


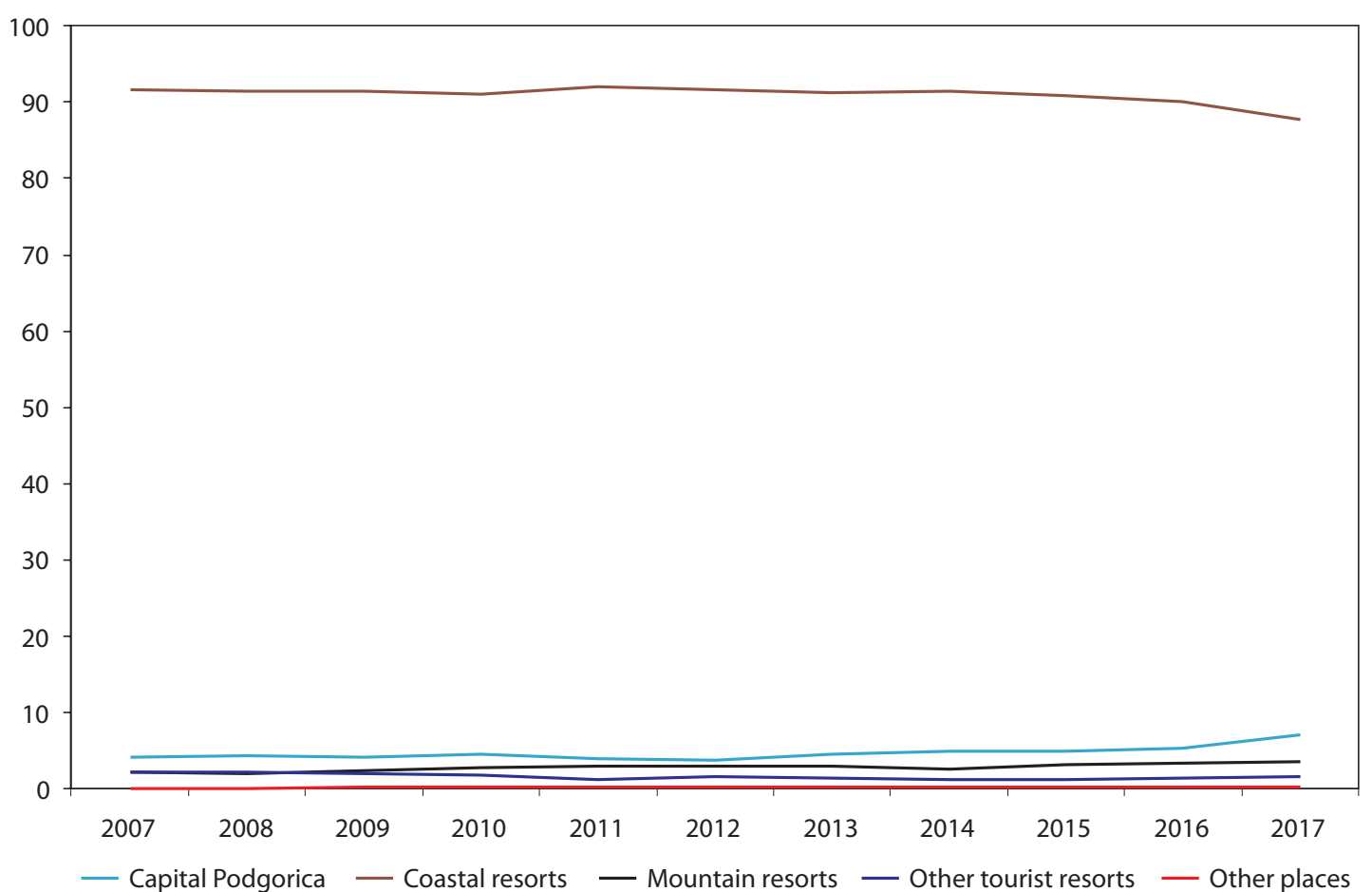

Fig. 3. The structure (in \%) of the number of tourists in designated areas in Montenegro.

Source: own study based on: Statistical..., 2009, 2013, 2018.

Their numbers grew by $6.3 \%$ year-on-year in the period under analysis. Podgorica was the second most popular destination and was visited by 40 thousand tourists in 2007 (4.1\%). Their numbers increased to nearly 132 thousand in 2017 (7\%). The third most popular destinations were the mountain areas which were visited by 21 thousand of international tourists (2.2\%) in 2007. The above mentioned destinations gained popularity during the entire period of Montenegro's independence. It also translated into the number of arrivals of over 64 thousand (3.4\%) in 2017. The highest value of the variation coefficient was estimated for Podgorica at $41.41 \%$ which indicates high variation in the tourist numbers. The second highest variation coefficient was estimated for the mountain areas at $36.07 \%$ and indicates moderate variation in the number of tourists visiting this area. The coastal areas showed the highest stability of international tourists number. The variation coefficient estimated for tourists in this area was $19.77 \%$, thus, it can be concluded that this area is characterized by low variation in tourist numbers. The variation coefficient estimated for the entire Montenegro at 20.98 indicates moderate variation in the number of international tourists.

International tourists accounted for nearly 6.5 million overnight stays in 2007 . Their numbers grew nearly every year except 2009 (decrease by 270 thousand overnight stays) and was as high as 11.4 million overnight stays in 2017. Most of the overnight stays, nearly 6.26 million in 2007, were made in the coastal areas. They constituted $97.2 \%$ of all overnight stays made by international tourists that year. Their number reached 10.99 million in 2017. However, their participation in the whole structure of overnight stays fell to $87.8 \%$. Podgorica ranks as a very popular destination. International tourists made over 80 thousand overnight stays in 2007 which accounted for $1.2 \%$ of the total number. The subsequent years showed an increase in the number of overnight stays. Over 228 thousand (2\%) overnight stays were made in 2017. In 2007, over 45 thousand overnight stays were made in the mountain areas of Montenegro which accounted for $0.7 \%$ of all overnight stays made in Montenegro by international tourists. By 2017, the number increased to over 154 thousand and accounted for $3.4 \%$ of all overnight stays. The highest value of the variation coefficient was estimated for the mountain areas at $40.29 \%$. It indicates high variation in the number of overnight stays. On the other hand, the value of the variation coefficient estimated for Podgorica was $36.73 \%$ and indicates moderate variation. The lowest value of the variation coefficient was estimated for the coastal areas at $19 \%$. It indicates low variation in the analyzed feature. The value of the coefficient for the entire Montenegro was estimated at 19.29\% and indicates low variation in the number of overnight stays nationwide.

The average number of overnight stays made by international tourists ranged from 6.11 to 5.76 . The longest stays prevailed in the coastal area where 
the average length of stay in the area under analysis ranged from 6.67 to 7.17 per tourist. In each of the years under analysis, the average length of stay by international tourists was longer than the average stay by domestic tourist by 0.83 nights. The greatest difference took place in 2017 and was 1.46 night. In the mountain area, the average length of stay ranged from 1.89 to 2.40 nights. In the whole period under study, the average length of stay made by international tourists was shorter by 0.67 night than the average length of stay made by domestic tourists. Only in 2017, international tourists spent there 0.36 night more on average than domestic tourists. In Podgorica, the average length of stay ranged from 1.73 to 2.00 . Each year under study, the average length of stay by domestic tourists was longer than the length of stay by international tourists by 1.06 night. The greatest difference occurred in 2007 and was 2.61 nights.

\section{The main national groups visiting Montenegro}

$50 \%$ of inbound tourists to Montenegro come from three countries: Serbia, Russia and Bosnia and Herzegovina. Those tourists generate over $60 \%$ of accommodation demand (exception: 2010 when the citizens of the three countries fulfilled $58 \%$ of the accommodation services for foreigners) (fig. 4).

Despite a decrease in the participation of Serbian tourists in the structure of international tourists, their numbers remained at a similar level. The variation coefficient for Serbian tourists was estimated at $12.11 \%$ and indicates low variation in their numbers. Citizens of the Russian Federation are the second most numerous group of tourists. Their numbers rose by $242 \%$ in the period under analysis whereas their participation increased from $10 \%$ to $23.58 \%$ in 2014 and then fell to $18.67 \%$ in 2017 . The variability coefficient estimated for the number of tourists was $36.67 \%$ and indicates moderate variation in the trait under study. The third most numerous group involved the citizens of Bosnia and Herzegovina. Their numbers fell to 101 thousand in 2007 and to 91 thousand in 2013. The variation coefficient for this group of tourists was estimated at $28.81 \%$ and indicates moderate variation in their number. Bosnia and Herzegovina's tourists made up10.3\% in 2007. The number fell to $6.79 \%$ by 2014 only to rise up to $10.72 \%$ in 2016 . It was $9.79 \%$ in 2017.

At the beginning of the period under study, the citizens of Serbia accounted for $41 \%$ of overnight stays made by foreigners (fig. 5). Their participation decreased in subsequent years to $25.66 \%$ in 2017. At the same time, the number of overnight stays

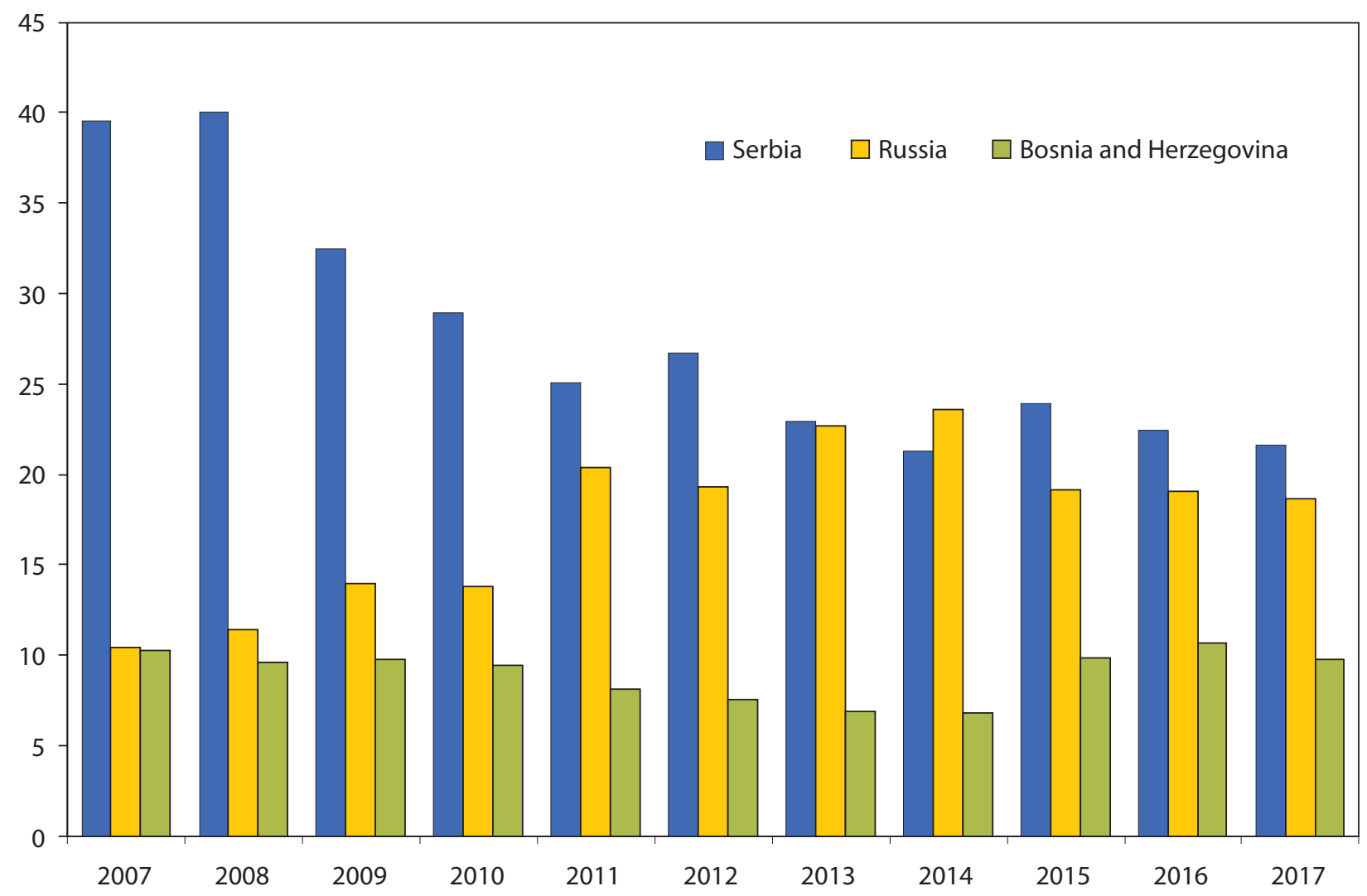

Fig. 4. Participation [in \%] of the citizens of Serbia, Russia and Bosnia and Herzegovina in inbound tourism Source: own study based on: Statistical..., 2009, 2013, 2018. 


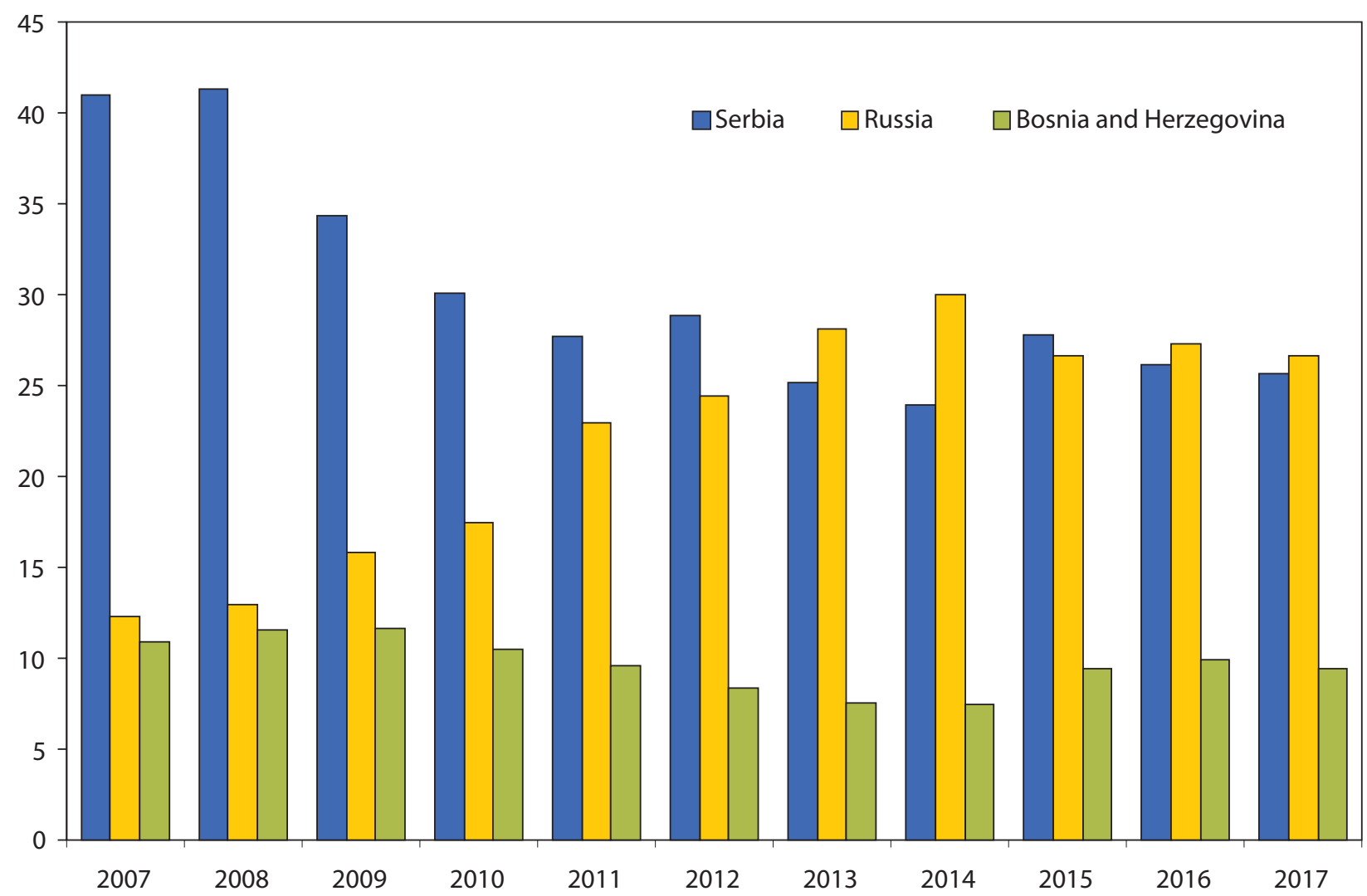

Fig. 5. Participation (in \%) of citizens of Serbia, Russia, Bosnia and Herzegovina in the use of accommodation facilities by inbound tourists.

Source: own study based on: Statistical..., 2009, 2013, 2018.

exceeded 2.6 million in 2007 and 2.9 million in 2017. The variation coefficient for the number of overnight stays made by Serbs was estimated at $50.8 \%$ in the period of 2007-2017 and indicates high variation. The second group in terms of the highest number of overnight stays are the citizens of the Russian Federation. Their numbers increased from 789 thousand in 2007 to 3.059 thousand in 2017. The variation coefficient estimated for the number of stays in this group reached $54.92 \%$ and indicates high variation in the phenomenon in question. At the same time, the group's participation in the structure of overnight stays made by international tourists rose from $12.25 \%$ to $26.67 \%$. The citizens of Bosnia and Herzegovina made up over 703 thousand overnight stays in 2007. Their numbers fluctuated to reach 1.083 thousand in 2017. The variation coefficient was estimated at $52.5 \%$ which indicates high variation in the described values. At the same time, the group's participation in the general structure of overnight stays remained at a similar level ranging from $7.46 \%$ to $11.62 \%$.

\section{Conclusions}

The analysis of the tourist traffic in Montenegro indicates that it is in the phase of growth. The number of tourists has been constantly on the increase since the country gained independence. Peaceful separation of Montenegro and Serbia was significant for the tourism development as it spared the country war damage and its historical monuments have been preserved. Tourism in Podgorica has been developing most dynamically whereas the coastal areas are the most popular with both domestic and international tourists. Montenegro was granted the longest part of the Yugoslavian coast after Croatia and has been taking the best advantage of it. However, Montenegrins should bear it in mind that overexploitation of the given area may have adverse impact on further growth of tourism.

It is important to remember that over $50 \%$ of tourism traffic is generated by only three markets. Therefore, the main tasks of the administration responsible for sustainable development of tourism in Montenegro should aim at diversifying the sources of tourist traffic. Deterioration of the economic or political situation in any of the three countries would have an irreversible impact on tourism in Montenegro as well as on the entire national economy. 


\section{References}

Čerović S., Knežević M., Pavlović D., 2016, The effects of tourism on the GDP of Macedonia, Montenegro and Serbia in the process of European Integration, Amfiteatru Economic, 18(42), 407-422.

Cimbaljević M., Demirović D., Nikola Vuksanović N., Milentijević N., Yamashkin A.A., 2019, A GIS-based analysis of tourist distribution in Montenegro, Journal of the Geographical Institute "Jovan Cvijic" SASA, 69(2), 147-156. doi: 10.2298/IJGI1902147C

Djurović P., Djurović M., 2016, Physical Geographic Characteristics and Sustainable Development of the Mountain Area in Montenegro, [in:] G. Zhelezov (ed.), Sustainable development in mountain regions: Southeastern Europe, $2^{\mathrm{ND}}$ Edition, SPRINGER INTERNATIONAL PUBLISHING AG, Cham, 93-111. doi: 10.1007/978-3-319-20110-8_8

Marti L., Puertas R., 2017, Determinants of tourist arrivals in European Mediterranean countries: Analysis of competitiveness, European Journal of Tourism Research, 15, 131142.

Marušić Z, Aleksić A., Bach M.P., Omazić M.A., Zoroja J., 2019, Determinants of innovation in hotel and travel agency service industry: impact of information and communication technologies and enterprise readiness, Interdisciplinary Description of Complex Systems, 17(1-B), 209-225. doi: 10.7906/indecs.17.1.19

Šilc U., Stevanović Z.D., Ibraliu A., Luković M., Steševi D., 2016, Human impact on sandy beach vegetation along the southeastern Adriatic coast, Biologia, 71(8), 865-874. doi: 10.1515/biolog-2016-0111

Smolović J. C., Janketić S., Jaćimović D., Bučar M., Stare M., 2018, Montenegro's Road to Sustainable Tourism Growth and Innovation, Sustainability, 10(12), 1-20. doi: 10.3390/ su10124687

Srdanović M., Dragoslav P., 2015, Tourists' attitudes on tourism offer in north-western part of Montenegro, Journal of the Geographical Institute "Jovan Cvijic" SASA, 65(2), 201-214. DOI: 10.2298/IJGI1502201S

Statistical Yearbook Montenegro - 2009, 2009, Montenegro Statistical Office, Podgorica.

Statistical Yearbook Montenegro - 2013, 2013, Montenegro Statistical Office, Podgorica.

Statistical Yearbook Montenegro - 2018, 2018, Montenegro Statistical Office, Podgorica.

Statuto D., 2017, Valorisation of vernacular farm buildings for the sustainable development of rural tourism in mountain areas of the Adriatic-Ionian macro-region, Journal of Agricultural Engineering, 48, 21-26. doi: 10.4081/jae.2017.643

Tkalec M., Vizek M., 2016, The price tag of tourism: does tourism activity increase the prices of goods and services?, Tourism Economics, 22(1), 93-109. doi: 10.5367/ te. 2014.0415

Violante A., 2017, Under Pressure: The Impact of Russian Tourism Investment in Montenegro, [in:] A. Hall (ed.), Tourism and geopolitics: issues and concepts from Central and Eastern Europe, CABI PUBLISHING-C A B INT, Oxon, 87-96.

Vučetić A.Š., 2017, Importance of environmental indicators of sustainable development in the transitional selective tourism destination, International Journal of Tourism Research, 20(3), 317-325. doi: 10.1002/jtr.2183

Vučetić A.Š., 2018, Influence of specialized hotels on employees' perception of abuse in the selective tourism destination, International Journal of Contemporary Hospitality Management, 30(2), 740-756. doi: 10.1108/ IJCHM-08-2016-0434

Wiskulski T., 2019, Uwarunkowania ruchu turystycznego z Polski do Chorwacji (Eng. Conditions of Polish tourism flow to Croatia), Wydawnictwo AWFiS, Gdańsk. 